\title{
Heirs of Abu Bakr: On the Ideology and Conception of History in al-Qaeda and Islamic State
}

\section{Jakob Skovgaard-Petersen}

University of Copenhagen, http://ccrs.ku.dk

\begin{abstract}
This article investigates references to early Muslim history by al-Qaeda and Islamic State, and notes a remarkable difference. While alQaeda has traditionally referred to the battles of the early Muslims during the time of the prophet Muhammad, the Islamic State centers its references on the successor to the prophet, the caliph Abu Bakr. Hence, AlQaeda, in line with Sayyed Qutb's notion of a "Qur'anic program," evokes a mythical past as if it is relived today. The Islamic State, in turn, takes a somewhat more pragmatic line, arguing that events today, like those of the earliest caliphs, are merely the outcomes of human decisions in a post-prophetic and post-Qur'anic age.
\end{abstract}

Keywords: Al-Qaeda, Islamic State, Abu Bakr, caliphate, ideology.

\section{Introduction}

Did the Caliphate cease to exist in 1924, or was it dissolved after the Mongolian invasion of Bagdad in 1258? Osama bin Laden and al-Qaeda (AQ) believed in the first claim, whereas Abu Bakr al-Baghdadi and IS seem to consider the second contention to be true.

This article will analyze the differences between the uses of historic references by the two movements, and discuss the implications. Despite the substantial resources invested in studying Islamic State (IS) in particular, this issue has not yet been the subject of systematic examination by researchers, and the current study is only a first attempt. The study will focus on a few central ideologies that use the early Islamic wars to justify present wars, though each in its different way. The article will examine how these ideologies have confronted each other over the past one-and-a-half years. 


\section{Phases of Jihadism}

As is generally known, the concept of Jihad in Muslim history has been used about a number of religious endeavors, e.g. asceticism, but in Islamic law and political thinking Jihad immediately takes on the meaning of war against nonMuslims. Today, the concept may be used in Arabic in entirely secular contexts, for instance class struggle or national endeavors. However, the meaning of war "for the sake of God" ( $f$ sabil Allah) is still the dominant understanding of the concept, and this conception has become even more pronounced over the past 50 years of Jihadism.

In Denmark, politicians and commentators generally do not use the term Jihadism, but rather Islamism, and there seems to be a general consensus that the phenomenon of Islamism was conceived in 1928, when Hassan al-Banna formed the Muslim Brotherhood in Egypt. This is also factually correct. However, Islamism is a multifaceted concept. As the word suggests, Islamism sees Islam as a political ideology and a model for organizing a nation and society. However, there is substantial disagreement on how a country and a society should be organized. Some Islamists reject parliamentary democracy, whereas others claim that it is mentioned in the Quran; and some Islamists reject constitutions, whereas others believe that the very concept of 'constitution' was introduced by Mohammad in Medina. The Danish foreign policy debate suffers from people using the concept of Islamism without being aware of its exact meaning; all they know is that they need to distance themselves from it. However, if no distinction is made between the different forms of Islamism, there can be no way of understanding what is going on in the Muslim world, or even among Muslims in Denmark. For example, in Syria, different Islamist groups are fighting on the side of the regime, or for the rebels or for IS.

IS are Islamists in the sense that they commit to an ideology of establishing ISs and societies. Their roots also go back to the Muslim Brotherhood and other Islamist movements. Yet today, they are highly critical towards the wider Islamist movements. Their strategic as well as their ideological standpoint is completely different and, therefore, I will use the term Jihadism here.

According to the Jihadist ideology, continuous Jihad is a duty for the individual Muslim, also in relation to those who claim to be Muslims, but who do not subscribe to this ideology; people who should be considered hypocrites or apostates in the sense of the Quran. As the true Muslims are therefore few in number and engaged in an unequal battle against the world's tyrants (tawaghit), they will most likely die in action. However, this is exactly what God expects of them, and His reward will be Paradise, as well as a guarantee that, as long as they remain on earth, the few true warriors will be victorious in the end (al-ta'ifa al-mansura).

This ideology of a small avant-garde group of true believers, who understand God's demand for war, was first formulated in the Arab world by Sayyed Qutb (1906-66) in the 1950s - the decade in which the Muslim states finally won independence. The ideology of the new states was based on nationalism, 
and the Islamist movements who saw Islam as a modern state ideology were marginalized and sometimes even relentlessly suppressed. From the 1970s, Qutb-inspired movements were established in various places, and, like the revolutionary socialists and nationalists, they believed that violence was a legitimate means of achieving their political goals. In the 1980s, these Jihadists went to Afghanistan, which had been invaded by the Soviet Union, and the al-Mujahideen (the Arabic word for "those who make Jihad") were financed, trained and armed by the Pakistani, Saudi and US intelligence services.

Having thus become professionalized, in the 1990s part of the Jihadist movement decided to launch a global Jihadist fight against US hegemony, which culminated with the attacks in 2001. In the fight against AQ, in which the US has been involved since then, many of the movement's leaders have been eliminated or taken prisoner, but the movement has not been effectively defeated. New ideological leaders, such as Abu Musab al-Suri, have pursued a strategy by which the movement is not concentrated in a (vulnerable) territory, but it is organized in loose, autonomous networks, not least in Europe. ${ }^{1}$ The renowned Jihadism researcher Gilles Kepel refers to this as the third phase of Jihadism, which follows the national and the global phases. ${ }^{2}$ In the Muslim world, another ideologist, Abu Bakr Naji, has advocated a strategy of using extreme violence to destabilize and control territories and make them ungovernable, so that their citizens gradually accept a tough Islamic law-and-order regime. The inspiration for this came from developments in Iraq, where a relatively successful US invasion in 2003 ran into severe problems when the toppled dictator Saddam Hussein's intelligence officers joined forces with the Jihadists from $\mathrm{AQ}$. $^{3}$

\section{Abu Muhammad al-Maqdisi and Abu Qatada}

The story above has been told many times. We will now move on and take a closer look at two other prominent Jihadist ideologists, who support $A Q$ and what they refer to as the global Jihadist movement. We will see these two ideologists contending with IS. They are both Palestinians from Jordan and both were born around 1960, just like me, but they have grown considerably longer beards.

Probably the most important of the two is Abu Muhammad al-Maqdisi (born in 1959). Al-Maqdisi grew up in Kuwait and studied at several universities, but he is mainly self-educated. From early on, his aim was to unite the re-

1 Brynjar Lia, Architect of Global Jihad. The Life of al-Qaida Strategist Abu Musab alSuri (London: Hurst and Oxford University Press, 2007), p. 7.

2 Gilles Kepel, Beyond Terror and Martyrdom (Cambridge, MA: Harvard University Press, 2010), p. 110.

3 Lars Erslev Andersen, "The Mole and the Mallet: Islamic State and al-Qaeda in the 'Thirty Years' War' in the Middle East," Connections: The Quarterly Journal 16, no. 1 (Winter 2017): 7-24, https://doi.org/10.11610/Connections.16.1.01. 
bel ideology of political Islamism with the conservative theology of Salafism, and he found a connection in classical Wahhabism. In his first book, Millat Ibrahim (1984), he modernized the classical Wahhabism by applying its traditional (Quran) term bara' (to refrain from and renounce polytheism, in the same way as Abraham) to present-day Muslim presidents and kings and their political systems. At the same time, he emphasizes that merely condemning with your heart is too weak; hatred and Jihad are more praiseworthy. Thus, he prepares the ground for confrontation with the political elite, but without accusing Muslims of heresy, if they are not willing to go that far. ${ }^{4}$ After the Palestinians were thrown out of Kuwait in 1991, al-Maqdisi came to Jordan, where he and a student, Abu Musab al-Zarqawi, established a militant group. Soon after he was imprisoned from 1994-1999. Since then, he has been in Jordan.

The other AQ ideologist is al-Maqdisi's friend, Abu Qatada al-Filstini (born in 1960). Abu Qatada is also self-educated and he also travelled in Pakistan in the late 1980s. However, he is primarily known as a preacher in London in the 1990 s, and for a lengthy trial resulting in his deportation from the UK to Jordan in 2013. Whereas al-Maqdisi has a calm demeanor, Abu Qatada is aggressive and likes to make provocative statements, clearly in order to raise awareness of Jihadism in wider circles and to recruit new fighters.

After the US and a coalition of countries went into Iraq in 2003, al-Maqdisi supported the struggle against the western forces, as did all other Jihadists. However, at the same time al-Maqdisi published several writings in which he criticized al-Zarqawi's use of extreme violence and suicide attacks, and his accusation of heresy - not only of Shia Muslims, but also of the Sunnis in Iraq. AlZarqawi responded with a statement against al-Maqdisi, in which he accused al-Maqdisi of raising his critique in order to secure his release from prison. ${ }^{5}$ The echo of this exchange in 2005 between the two ideologists could be heard 10 years later when al-Maqdisi, again from a base in Jordan, criticized IS, who acclaim al-Zarqawi as their ideological founder.

\section{Who, then, are the IS ideologists?}

IS also have their ideologists, and just like al-Maqdisi and Abu Qatada, they do not have long careers in the established Islamic research institutions. On the contrary, they want to break away from established Islam.

The most prominent IS spokesperson was Muhammad al-Adnani who was killed in an US air attack in the summer of 2016. He was actually Syrian, from the northern town of Binnish, where he was born in 1977 and given the name Taha Subhi Falaha. Although they have been to Pakistan, al-Maqdisi and Abu Qatada are only ideologists, but al-Adnani was an actual warrior. He took part in the rebellion against the US invasion troops in Iraq in 2003, and here he met

\footnotetext{
4 Joas Wagemakers, A Quietist Jihadi. The Ideology and Influence of Abu Muhammad al-Maqdisi (Cambridge: Cambridge University Press, 2012), pp. 170-173.

5 Wagemakers, A Quietist Jihadi, p. 48.
} 
Abu Musaab al-Zarqawi. Al-Zarqawi was the leader of AQ in Iraq, but friction with the leaders in Pakistan caused him to go his own way until he was killed in 2006. Al-Adnani spent some years in prison and became part of the inner circle of IS in Iraq. He was the obvious choice when the movement went into Syria in 2012, and it was he who proclaimed the Caliphate at the beginning of Ramadan in 2014.

The other ideologist from IS is the young Turki Bin'ali, who was born in Bahrain in 1984. After short periods of study in Bahrain, Beirut and Dubai, he attracted attention as a dedicated disciple of Muhammad ibn Abd al-Wahhab, the puritan 18th century thinker, who is a kind of national ideologist in Saudi Arabia. ibn Abd al-Wahhab was opposed to any kind of religious innovation and urged for armed reaction against anyone not following his puritan interpretation of Islam. Today, Saudi Arabia is not as Wahhabist as it used to be, and Bin'ali and IS blame the monarchy for this development. They publish Muhammad ibn al-Wahhabs writings on the internet, pinpointing discrepancies with modern Saudi Arabia, and they are behind the bombings of the Shiite minority in the country, who have been marginalized by the monarchy, but who have not-as ibn Abd al-Wahhab would have preferred-been completely eliminated. In April 2014, Turki Bin'ali published a statement providing the legal justification for establishing a caliphate, even though not all preconditions are present. The reasoning behind this was to speed up the process based on the Quran 24:55, in which God is said to promise that he will reward the true believers with a caliphate. Al-Adnani used this argument in his announcement of the Caliphate, "God's Promise."

\section{How to become a caliph}

The 2011 rebellion in Syria quickly led to the Jihadist movement in Iraq moving into the Syria; first personalized by Abu Muhammad al-Jawlani and the Jabhat al-Nusra front group, and later on by Abu Bakr al-Baghdadi and IS in Iraq and the Levant (ISIL or ISIS). AQ's international leader, Ayman al-Zawahiri, supported the former front group, and in the winter of 2014-15, the two movements were fighting each other. The al-Nusra front and their allies won.

However, as soon as the following summer, ISIS succeeded in conquering the major Iraqi city of Mosul in a surprise attack, and from this very city, alBaghdadi was proclaimed the first Caliph of al-Adnani on the symbolic date of the first Ramadan. ISIS changed its name to IS and since then, the movement has "remained and expanded" (the movement's slogan) in the western part of Iraq and the eastern part of Syria, albeit with growing casualties. On the Friday following the proclamation, the Caliph held his inaugural sermon in the Great Mosque of al-Nuri, citing the first Caliph Abu Bakrs' famous words from his inaugural sermon in 632: "If I do well, help me; and if I do wrong, set me right."

A few days later, Abu Qatada sent out a statement to the Caliphate in which he condemned the new Caliph as illegitimate (batil). According to Islamic law, the Caliph should have been appointed by a council of qualified Muslim repre- 
sentatives (ahl al-shura - Jihadist leaders from all over the world). In an interview with the international newspaper al-Sharq al-Awsat from his prison cell in Jordan, Abu Qatada interpreted the statement as a strategic move, which did not address all Muslims, but was simply an attempt to get ahead of the larger AQ-oriented Jihadism. Furthermore, he stated that al-Baghdadi's methods "combined failed elements from al-rawafid and al-khawarij." ${ }^{6}$ This is a serious accusation in the Jihadist universe; al-rawafid is an abusive term for Shia Muslims, and al-khawarij (the Khawarij), is the religious direction which caused disputes among Muslims shortly after the Prophet's death because of its rigid and intolerant view on who could be a Muslim and who could be a leader, and because it was responsible for the death of the fourth Caliph, Ali.

The latter point of criticism had already been raised by Turki Bin'ali in the spring. In a ten-page "Statement in response to Abu Qatada," Bin'ali speculated on how a man like Abu Qatada, who had published books of such magnitude and importance, could backstab the Mujahideen. It could only be due to lack of knowledge of their situation and an unfortunate development in prison. Bin'ali suggested that Abu Qatada was simply being used as a tool by the Jordan intelligence services. He concluded that Abu Qatada's books can still be trusted, but that it is no longer possible to have confidence in any statements he makes from prison.

After the announcement of the Caliphate, Muhammad al-Adnani, IS's other chief ideologist, issued an even tougher response to the movement's Jihadist critics: people may listen to Muslim scholars from all over the world. But they can also see who is winning. We are. So, we have the support of God. Muhammad al-Maqdisi has also had numerous disputes with the leaders of IS. As the mentor of al-Zarqawi, who IS considers to be its first leader, he believed that he could influence IS when Mu'adh al-Kasasiba, a Jordanian pilot, was shot down and IS announced that they would execute him. But not only was al-Maqdisi unable to save al-Kasasiba; he also discovered that IS had in fact executed the pilot while they were negotiating with al-Maqdisi. ${ }^{7}$

In short, there was not much mutual respect. The culmination of the poor relationship came when both al-Maqdisi and Abu Qatada signed a fatwa which allowed the true Mujahideen to defeat IS in self-defense. They called IS "Baghdadis," i.e. supporters of a sect led by al-Baghdadi. ${ }^{8}$ At that time, IS and Jabhat al-Nusra were in direct confrontation at Aleppo.

6 Muhammad Al-Da'ma, "al-da'iyya al-urduniyya al-mutashaddad Abu Qatada yantaqad I'lan al-khilafa al-islamiyya," Al-Sharq al-Awsat 16, no. 7 (2014), available at http://aawsat.com/home/article/139131.

7 Joas Waagemakers, Al-Maqdisi in the Middle. 2015; available at http://www.jihadica.com/maqdisi-in-the-middle-an-inside-account-of-the-secretnegotiations-to-free-a-jordanian-pilot/.

8 Abu Qatada al-Filastini, Muhammad al-Maqdisi et al.: Fatwa, June 3, 2015, available at http://www.jihadica.com/wp-content/uploads/2016/05/fatwa-June-3-2015.pdf. 
Abu Qatada and al-Maqdisi are not the only ideologists with links to AQ, and who have had confrontations with al-Adnani, but they are among the most famous, and the fights between them have been going on intermittently for some time, most recently in May 2016, when IS published a long document, "Obliteration of the icons." This document argued that the Jihadist ideologists who have expressed their sympathy with the Muslim Brotherhood should not be considered part of the movement of true believers, because the Brotherhood has accepted parliamentarism, cooperation with the infidel, etc. ${ }^{9}$ The document was targeted at the AQ ideologist, Abu Musaab al-Suri, but could also have been targeted at Abu Qatada, who, after the revolutions in 2011, was encouraged by the public support for the Islamist movements, although he believed that they should immediately be challenged. ${ }^{10}$ Only two days after the publication of "Obliteration of the icons," al-Maqdisi released a statement saying that this obliteration, which also included the religious martyrs, showed that IS had developed into an extremist sect (ghulw), which was also parting with its own more knowledgeable ideologists. ${ }^{11}$

\section{The history of the Caliphate}

The different interpretations of political authority are also reflected in the different datings of the fall of the Caliphate. Osama bin Laden seems to follow the same course that we know from Hizb-ut-Tahrir in Denmark. This view holds that the western powers, including the early Zionists, decided to undermine the Ottoman Caliphate, first in 1876 with the introduction of a constitution, and again in 1908 with the Young Turk Revolution, when nationalists deposed the pious Abd al-Hamid II and instated another Caliph who they could control. A third occasion was in 1924 when the newly established Turkish Parliament decided to abolish the office of caliph.

For IS, the Ottoman Caliphate was not a real caliphate because the Ottoman did not descend from the Prophet's tribe, Quraish. In their view, the Caliphate fell 750 years ago, with the Mongolian invasion of Bagdad and the assassination of al-Musta'sim, the last Abbasid Caliph, who was wrapped up in a carpet and drowned in the Tigris. The Abbasid Dynasty, which ruled from 750 to 1258 , were true descenders of the Quraish, but had become weak over time. For IS, the foundation of the dynasty around 750 is therefore the primary source of inspiration. Carrying black banners, the rebels came from Khorasan (an area which now covers the north-eastern part of Iran and the southern part of Cen-

9 Abu Maysara al-Shami, Tamas al-rumuz (2016), available at https://azelin.files.wordpress.com/2016/05/abucc84-maysarah-al-shacc84micc8422obliteration-of-the-icons-abucc84-muscca3ab-al-succ84ricc8422.pdf.

10 Abu Qatada al-Filastini, al-Muqaraba li nazilat al-'asr. Copenhagen: al-Nur, 2012.

11 Muhammad Al-Maqdisi, al-radd 'ala Abu Maysara, 2016, available at http://jihadology.net/2016/05/14/new-release-from-shaykh-abu-mu\%e1\%b8\%a5 ammad-al-maqdisi-reply-to-abu-maysurah-on-seeking-to-obliterate-the-icons/. 
tral Asia) to fight the morally corrupt Umayyad dynasty in Damascus. The Abbasid capital was temporarily located in Raqqa before it was moved to Bagdad - a dream that IS also has. IS consciously draws these parallels: the movement uses the same flag, and they name their territories after the old Abbasid provinces (wilayat). Furthermore, the Caliph has taken the name al-Baghdadi alQuraishi, which means that he is a descendent of Quraish and that he is from Bagdad. Originally, his name was Ibrahim Awwad Ibrahim al-Badri, and he actually comes from another Iraqi town, Samarra. However, what is more important is the first name he has taken: Abu Bakr.

\section{Abu Bakr}

Abu Bakr was the Prophet's close friend and brother-in-arms. He also succeeded the Prophet, and the word caliph means "a successor to the Prophet." In 632, on the night the Prophet died, there was a major council (shura) to discuss the future. There were several candidates for the leadership, but everything was settled when Umar, one of the Prophet's brothers-in-arms, with loud and clear voice pledged allegiance $\left(b a y^{\prime} a\right)$ to Abu Bakr, and the others followed suit. Soon after, Umar himself became the Caliph, when Abu Bakr died in 634.

IS sees Abu Bakrs' two years in power as the guiding light for their strategy and legitimacy, because this period represents the time when a state was gradually taking shape, although many aspects of the state were still very cloudy. Firstly, many Arab tribes broke their alliance with the Muslims because they considered their oath to be a personal oath of allegiance to Muhammad, who had now died. Therefore, Abu Bakr had to spend most of his time and effort on wars against these tribes, forcing them to renew their oath. The wars are known as the Ridda wars, which means the wars against the apostates. IS uses the same term for their wars against the Arab tribes in Syria, and especially in Iraq, where the tribes joined forces with the US in a rebellion against IS in Iraq (ISI), a forerunner of IS. Since 2014, the tribes have either been defeated or co-opted. Subsequently, some have simply been slaughtered, whereas others have been forced to pledge allegiance to Abu Bakr at great ceremonies, and participate in re-education programs which are claimed to be modelled on $\mathrm{Ca}$ liph Abu Bakr's education of the Arab tribes. ${ }^{12}$ The IS slogan "to remain and expand" is based on the defeat of apostasy and the brave attacks on new areas (and financially important war booty).

In a long article in its French propaganda magazine "Dar al Islam" in May 2016, IS explains how it diligently follows in the footsteps of Abu Bakr and the companions of the Prophet.

It is thus necessary-today more than ever-to go back in time to the stories about our pious ancestors, the Prophet's companions, to analyze and compare their work with that of IS. Only by making this comparison can

12 Michael Weiss and Hassan Hassan, ISIS. Inside the Army of Terror (New York: Regan Arts, 2015), pp. 200-210. 
genuine seekers of the truth assure themselves that today, IS marches in the footsteps of the companions [...] Since the Caliphate is now being established, and all nations of infidelity and apostasy have joined forces to fight it, it is time to turn to the history of the Islamic conquests [...] In this article we invoke the battles led by Caliph Abu Bakr al-Siddiq, in particular the conquest of Iraq, which is the vital issue demanding our attention today. ${ }^{13}$

The main point of the article is that Abu Bakr chose to attack the much bigger and stronger Persian Sasanian Empire, which had expanded into what is currently known as Iraq, even though he was simultaneously engaged in the Ridda wars against the apostate tribes. So, he redirected his forces towards the north and the harbor town of Ubullah, and further on to al-Hirah, the major Persian city in Mesopotamia. Remaining and expanding at the same time was an enormous venture. But this unequal battle was a conscious strategy by Abu Bakr, because he knew that God would not allow the Ummah to be destroyed. In this way, Abu Bakr established the state and its true Muslims, who are Mujahideen, and the false believers, the hypocrites, were eliminated. Using a crisscross of various battles, Abu Bakr's speech to his soldiers and quotes from the IS ideologist Abu Muhammad Adnanis, the article demonstrates that IS is diligently following the strategy of Abu Bakr:

This is the secret of IS and its battles today. It never relies on its force or its preparation or its number. It relies fully on God, because only God can ensure victory: 'And there is no victory except from Allah, the All-Mighty, the All-Wise' ([Quran Surah 3] Al Imran, verse 126). The message from Abu Bakr as-Siddiq to his soldiers is the key to victory. Therefore, the commanders of IS have had no other choice than to send the same message to their soldiers. Sheikh Abu Muhammad al-Adnani said: 'Soldiers of IS, listen to these words. Have no fear for the Caliphate, because Allah (may He be exalted and praised) will protect and shape the Caliphate and the people who establish

it. But have fear for yourself, fear for your souls, make them accountable in remorse and come back to your Lord. ${ }^{14}$

The intention is to make IS soldiers fight against apostasy, and those who die fighting for this cause are promised admission to Paradise. The article gives examples of early conquests when individual warriors and small groups who, thanks to their contempt for death, defeated much larger hostile contingents. The moral of the article is precisely the IS moral: even today, wars are won by those who are not afraid of death, but who love it.

\footnotetext{
13 "L'ètat islamique sur les par des compagnons," Dar al islam, May 9, 2016, p. 7.

14 Ibid., p. 11.
} 


\section{Abu Qatada and the Prophet's wars}

This last theme-that Islam will prevail because faithful Muslims have higher morals than other soldiers - is well-known in Islamist writings. ${ }^{15}$ However, they see Jihad as a defensive war to protect, for instance, a Muslim Palestine.

The notion of Jihad as an offensive war and individual duty is a trademark of ideological Jihadism, whose spiritual father in the Arab world is Sayyid Qutb. In his sizable Quran commentary "In the Shade of the Qur'an" from 1958, Qutb develops the idea that the true believer must abandon the impious and barbarous society he was born into and the sinful life he has led. Qutb calls it hijra, the word also used about the Prophet Muhammad's exodus from sinful Mecca to Yathrib, the city where the first Muslim society was founded. Like the Prophet, any Muslim must make his hijra, says Qutb, but only few-the avantgarde-did so. Because so few have realized the true Islam, we are still living in a 'time of weakness,' individually and collectively.

$A Q$ and many of the movement's ideologists have been inspired by the perception of the Prophet's life as a model for the struggling believer and the Quran as a program (minhaj): They want to see the establishment of the Jihadist movement in Afghanistan as the hijra of the small group of believers, and the battles fought from there as a model of the battles the Prophet fought from Yathrib (which he named Medina) against the Muslims' previous oppressors in pagan Mecca. The ideologists describe their various terrorist acts, including the attack on the World Trade Center in 2001, as 'raids,' or ghazwa, which is the origin of the word "razzia," and the word used by Muslim historians about Mohammad's attacks on the caravans from Mecca.

Abu Qatada has written a review of the Prophet Muhammed's raids, which is intended as an instruction for today's Mujahideen. Over 732 pages in Arabic, he goes through the almost 20 large and small raids conducted by the Prophet during a period of nine years from 624 to his death in 632. This has been done before, based on biographies of Muhammad by Muslim historians. However, Abu Qatada's idea is different because he focuses on verses in the Quran revealed in connection with the individual battles and on how God builds up the Ummah and each individual Muslim. The wars are stages in God's program for the true believer, a divine formation of character.

Therefore, Abu Qatada devotes more than a quarter of the book to one particular raid, which ended in a defeat, namely the Battle of Uhud. The Muslims reacted differently when they were faced with a superior Meccan army; the warriors were unsettled, some went out too early, whereas others never went. It was a tough time for everyone, because the defeat at Uhud came after a miraculous victory at Badr, which had made the Muslims overly confident and careless. Abu Qatada is full of praise for the Battle of Uhud, because it led to a separation of the true believers and the hypocrites, and it offered an oppor-

15 Sami E. Baroudi, "Sheikh Yusuf Qaradawi on International Relations: The Discourse of a Leading Islamist Scholar (1926-)," Middle Eastern Studies 50, no. 1 (2014): 2-26. 
tunity for many warriors to achieve martyrdom. At Uhud, God made it clear that Jihad is life itself and the only way to bear testimony to God. ${ }^{16}$ God revealed, among other things, the verse "Allah loves the steadfast" (Qur'an 3:146) because the battle was the greatest ordeal for the early Muslims. Patience does not mean tolerance, but steadfastness. It is not the humbleness of animals or subjects; it is the faithful, patiently waiting for the right opportunity. ${ }^{17}$ Therefore, Abu Qatada does not see Jihad as killing, but as part of a civilization process: the formation of a nation and a person. He ends his review by stating that Jihad is the deed of a nation; something one should be brought up in. Inspired by Sayyed Qutb, he states that only the mujahedeen will be free, because Jihad means liberation and self-liberation. Abu Qatada concludes by encouraging any young man who reads the review to confront his selfish soul and its bad excuses, and to choose the only thing that can save a human being, namely Jihad. ${ }^{18}$

One reason that Abu Qatada spends so much energy on the Battle of Uhud and speaks of it with gratitude is that this battle was the great ordeal which was needed to separate the "victorious group" from the true mujahedeen. However, another reason is that, in his interpretation, this is also where the Muslims are in the present day (the book was published in 2012). God is testing the Mujahideen in his great ordeal. They won a surprising victory over the Soviet Union in Afghanistan, and they miraculously succeeded in attacking the biggest city in the US. But since then, the Americans have launched a counterattack, Osama bin Laden has been assassinated, and yes, some Muslims have defected. Now more than ever, there is a need for high morals and contempt of death: the Mujahideen must love the ordeal imposed by God.

\section{Conclusion}

IS and AQ are rivals in Syria, Yemen, North Africa and many other places. As described in other articles in this special issue, the two movements have different strategies in relation to the local Muslim populations, and different views on the use of extreme violence. Another main difference is that IS controls a welldefined territory which the movement claims to be a state with certain state functions. Many of the videos coming from IS do not show violence, but rather schools, courts, police, markets and obedient citizens. And this is another important difference: IS is deeply concerned with the coming of the Caliph and people pledging allegiance to him. If they do not, they are apostates and must be killed. As we have seen, this is one of the main differences from ideologists like al-Maqdisi and Abu Qatada.

This chapter has dealt with the movement's notion of the caliphate and political authority, and the conception of history in which it is rooted. Again, the

\footnotetext{
16 al-Filastini, al-Muqaraba li nazilat al-'asr, p. 116.

17 Ibid., p. 145.

18 Ibid., p. 461.
} 
contrast to $A Q$ is evident. In AQ's ideology, the caliphate is a thing of the future that Muslims will realize one day, but it has not been the movement's primary focus. The faithful are still far too weak. Instead, they need to consolidate. They are like the very first Muslims who migrated from Mecca in the exodus led by Mohammed, and who started a prolonged war against the city. They are at a specific juncture in this war; in the slump following the Battle of Uhud and the defeat which separated the sheep from the goats. This was in 625 .

IS, on the other hand, is mentally in 633. The Prophet is dead, Abu Bakr is the chosen one and has held his inaugural speech, and the rebellion of the Arab tribes has almost been defeated. The battle to be fought is not the Battle of Uhud, but the Battle of Ubullah, and after this comes the annexation of Iraq and the fall of the Persian Empire. Whereas in AQ's ideology the Muslims are fighting their way out of a state of weakness and are highly defensive, IS's ideologists find their movement to be in another position: they are remaining and on the verge of expanding, with great Muslim conquests. They have already minted their own currency, the dinar, and appointed governors for distant provinces. It is still a time of ordeal, and the Prophet is no longer alive. But God has created the victorious group, and now it is time to build the state and to expand.

\section{About the author}

Jakob Skovgaard-Petersen is associate professor of Arabic and Islamic studies at the University of Copenhagen. His field is contemporary Islamic media and thinking, and the contemporary role of the Muslim scholars, the ulama. 